\title{
TINGKAT KECEMASAN PESILAT GRAND FINAL SIRKUIT NASIONAL PENCAK SILAT 2006
}

Oleh: Tonang Juniarta, Siswantoyo

Dosen Jurusan Pendidikan Kepclatihan Olahraga

\section{Abstrak}

Penelitian ini merupakan penelitian deskriptil yang bertujuan untuk mengetahui tingkat kecemasan pesilat grand final sirkuit nasional pencak silat 2006. Populasi dadaun penelitian ini adalah scluruh pesilat grand linal sirkuit nasional pencak silat 2006 yang berjumlah 188 pesilat. Sampel inklusi penelitian berjumlah 153 pesilat yaitu pesilat yang mengisi dan mengembalikan angket. Teknik pengumpulan data menggunakan angket yang disusun berdasarkan tujuan penelitian, uji validitas menggunakan korelasi Product Momcnt dari Pearson, uji reliabilitas menggunakan rumus Alpha Cronbach. Teknik analisis data dengan menggunakan tcknik analisis statistik deskriptif yang dituangkan dalam bentuk persentase.

Hasil penelitian menunjukkan bahwa tingkat kecemasan kognitif pesilat peserta grand final sirkuit nasional pencak silat 2006 termasuk dalam kategori rendah scbesar 5.5,6\% $\%$ pesilat), kategori sedang scbesar $43,1 \%(66$ pesilat), dan kategori tinggi sebesar $1,3 \%$ (2 pesilat). Tingkat keccmasan somatil termasuk dalam kategori rendah scbesar 77,8 \% (119 pesilat), katcgori sedang scbesar 20\% (32 pesilat), dan kategori tinggi sebesar 1,3\% (2 pesilat). Tingkat kecemasan secara kesclurulıan

MEDIKORA Vol.III, No 1, April 2007: 130)-1 1.8 
yang masuk dalam kategori rendah schesar 73,2\% (112 pesilat), kategori sedang sebesar 26,1\% (4.) orang), dan katcgori tinggi sebesar 0,7\% (1 orang). Dengan demikian disimpulkan bahwa tingkat kecemasan pesilat grand linal sirkuit nasional pencak silat 2006 mempunyai kecenderungan rendah.

Kata kunci: keccmasan, pesilat, kognitil, somatil, grand linal.

Kecemasan merupakan permasalahan psikologis yang scring muncul pada atlet pencak silat. Kecemasan yang tinggi dapat menggangyu penampilan atlet dalam pertandingan. Kecemasan merupakan permasalahan psikologis, namun demikian pengaruh yang ditimbulkan sampai pada aspek lisiologis. Aspek mental yang merupakan bagian dari psikologi atlet memegang peranan penting dalam sebuah pertandingan pencak silat, maka penting bagi pelatih untuk mengetahui tingkat kecemasan atlet. Dengan demikian pelatih diharapkan bisa mempersiapkan atlet secara "utuh".

Pencak silat berkembang scbagai olahraga prestasi yang ditandai dengan iklim kompetitil yang tinggi, schingga mendorong para atlet untuk selalu berlatih meningkatkan kemampuannya. Olahraga prestasi sclalu mengandung unsur persaingan yang diakhiri dengan penilaian "menangkalah" terhadap pihak-pihak yang ikut scrta dalam pertandingan terscbut. Scorang atlet yang bertanding dalam situasi kompetisi dipengaruhi olch berbagai faktor, yaitu laktor lisik, tcknik, taktik, dan psikis.

Pembinaan olahraga merupakan hal yang kompleks, artinya bahwa banyak faktor yang terlibat dan menentukan kebcrhasilan latihan. Prestasi olahraga yang tinggi tidak akan terlepas dari proses yang panjang dan tidak bisa dicapai secara tiba-liba (instant), mclainkan ada banyak hal yang

Tingkat Kecemasan Pesilat Grand Final Sirkuit Nasional (Tonang, Siswantoyo) 
berpengaruh. Ada ungkapan lilosolis yang menyalakan bahwa "juara harus dibuat" (champion has to be made). Hal tersebut mengandung pengertian bahwa prestasi yang tinggi dapat dicapai apabila seorang atlet giat berlatih secara kontinyu dan terarah, selain didukung bakat yang dimiliki individu scjak lahir.

Dalam pola pembinaan olahraga secara umum pembinaan harus dilakukan menyeluruh yang meliputi scmua aspek latihan yaitu; aspek lisik, teknik, taktik dan psikis. Namun, dalam pembinaan olahraga saat ini kcbanyakan pelatih yang menerapkan pola latilıan dengan dominasi pada latihan aspck fisik saja tanpa memberi porsi yang lebih terhadap faktor lain misalnya faktor psikologis atlet. Psikologis atlet meliputi motivasi, kepribadian dan sikap mental atlet, percaya diri, disiplin dan penguasaan diri, stres, kecemasan dan frustasi. Faktor psikologis perlu dilatihkan secara scimbang sehingga atlet mampu mengatasi permasalahan mental yang muncul pada atlet. Meningkatnya stres dalam pertandingan dapat menycbabkan atlet bereaksi secara negatif, baik dalam hal lisik maupun psikis, schingga kemampuan olahraganya menurun. Atlet terscbut dapat menjadi tegang dan diikuti dengan denyut nadi meningkat, berkeringal dingin, cemas akan hasil pertandingannya, dan mercka merasakan sulit berkonsentrasi. Kcadaan ini seringkali menyebabkan para atlet tidak dapat menampilkan permainan yang terbaik (http/www.bulutangkis.com). Kemampuan atlet untuk mengatasi gangguan-gangguan tersebut diharapkan dapat mendukung pencapaian prestasi yang maksimal.

MEDIKORA Vol.III, No 1, April 20()7: 13()-148 
Keccmasan merupakan salah satu gangguan psikis atlet. Kecemasan yang tinggi sangat mengganggu dan merugikan kincrja (pcrformance) atlet untuk mencapai prestasi terbaik. Gangguan tersebut akan terlihat dengan adanya gejala-gejala yang muncul baik sccara lisiologis maupun psikologis (Sukadiyanto, 2005: 6). Kelcmahan pada laktor mental akan memberi dampak yang besar terhadap kematangan yang sudah dicapai olch ketiga faktor lainnya. Faktor mental ibarat obor yang dapat menyulut penampilan yang baik seorang atlet. Pendapat Fisher yang dikutip olch Sukadiyanto (2005: 6) menyatakan bahwa pengaruh cmosi dalam olahraga dapat mengubah perilaku sescorang, mengganggu koordinasi gerak yang halus dan gerak yang kompleks, scrta menghambat kincrja di lapangan.

Orientasi pembinaan olahraga pada aspek lisik, teknik dan taktik menyebabkan aspek psikis sering terabaikan, padahal aspck psikis sangat penting dalam pencapaian prestasi linggi. Aspck psikis scringkali scbagai pemicu atlet untuk mengeluarkan penampilan terbaiknya. Latihan aspek psikis perlu ditingkatkan tanpa mengurangi aspek yang lain karena hubungan antar aspek tersebut saling berkaitan satu dengan yang lain.

Seorang atlet juga manusia yang pada saat tertentu pernah mengalami gejolak cmosional scperti; rasa takut, cemas, marah, kckhawatiran dan kebingungan. Faktor psikologis yang mempengaruhi scorang atlet dalam situasi kompetisi adalah kecemasan. Untuk dapat berprestasi dalam olahraga, atlet tidak hanya mengandalkan kemampuan motorik saja, tctapi juga harus bisa mengatasi kecemasan yang sering muncul dan gangguan psikologis yang lain. Kecemasan atlet seringkali muncul scbelum, sclama, dan sctclah 
bertanding. Pada atlet professional yang sudah berpengalaman di lingkat internasional, kecemasan juga masih dirasakan. Kcadaan-kcadaan psikologis seperti kecemasan perlu diketahui scbelum atlet tersebut terjun dalam pertandingan sesungguhnya. Untuk itu pelatih perlu melakukan pendekatan secara psikologis kepada atlet yang dibina.

Dalam pertandingan yang kompetitif kecemasan ini sering muncul secara berlebihan sehingga mengganggu penampilan atlet di lapangan. Kecemasan yang berlebihan seringkali muncul pada atlet di berbagai cabang olahraga. Scmakin tinggi kualitas dan tingkat pertandingan yang dihadlapi, maka ada kecenderungan kecemasan pada atlet akan semakin meningkat. Olahraga pencak silat merupakan olahraga dengan resiko cedera yang relatil tinggi, hal ini dikarenakan pencak silat merupakan olahraga body conlact. Pada olahraga body contact sclalu terjadi benturan lisik secara langsung sehingga akan mudah memancing munculnya perasaan cmosi pada olahragawan. Kecemasan merupakan bagian dari gejala cmosi yang muncul pada atlet. Pada kadar yang tinggi kecemasan akan mengganggu pencapaian prestasi atlet.

Apabila tingkat kecemasan pesilat sudah diketahui dapat digunakan sebagai acuan untuk melatih mental pesilat dan mengelola kecemasan tersebut dengan baik scbagai pendukung pencapaian prestasi yang tinggi dalam pertandingan pencak silat berdasarkan usaha latihan keras yang tclah dilakukannya berhari-hari, berbulan-bulan bahkan bertahun-tahun. Berdasarkan uraian di atas, maka penelitian tentang tingkat kecemasan pesilat grand final sirkuit nasional pencak silat 2006 perlu untuk dilakukan.

MEDIKORA Vol.III, No 1, April 20()7: 13()-14.8 


\section{Hasil Penelitian}

Penelitian ini dilaksanakan pada tanggal 15-19 November 2006 di Padepokan Pencak Silat Indoncsia, Taman Mini Indonesia Indah Jakarta. Untuk mengetahui tingkat keccmasan khususnya keccmasan scbclum bertanding pesilat grand linal sirkuit nasional pencak silat 20)6, dengan menggunakan angket scjumlah 32 butir pernyataan yang mcliputi 12 butir pernyataan untuk mengungkapkan kecemasan kognitif dan 20) butir pernyataan untuk mengungkapkan kecemasan somatil. Inntuk memudahkan dalam mendeskripsikan data hasil penclitian tersebut, maka dibuat kategori, yaitu: rendah, sedang, dan tinggi. Untuk menentukan interval dari ketiga kritcria pengelompokan skor di atas dibual kurva normal terlebilı dahuulu. Adapun deskripsi hasil penclitian adalah scbagai berikut:

1. Tingkat Kecemasan Kognitil Pesilat Grand linal Sirkuit Nasional Pencak Silat 2006

Dari 12 butir pernyataan katcgori kecemasan kognitil didapat rentang skor yang diharapkan 12-18. Dari data terscbut diperolch range scbesar 36 dengan mean 22,9150), median 22,(0)()(), modus 18,00, dan Standar Deviasi 5,03795.

Tabel 1: Distribusi Frekuensi Tingkat Kecemasan Kognitif Pesilat Grand final Sirkuit Nasional Pencak Silat 20)(60

\begin{tabular}{|l|c|c|c|}
\hline Katcgori & Interval Kelas & Frekuensi & Persentase \\
\hline Rendah & $12-24$ & 85 & $55.55 \%$ \\
\hline Sedang & $>24-36$ & 66 & $13.14 \%$ \\
\hline Tinggi & $>36-48$ & 2 & $1.31 \%$ \\
\hline \multicolumn{2}{|r|}{ Jumlah } & 153 & $100 \%$ \\
\hline
\end{tabular}


2. Tingkat Keccmasan Somatif Pesilat Grand linal Sirkuit Nasional Pencak Silat 20066

Dari 20 butir pernyataan kecemasan somatil didapat rentang skor yang diharapkan antara 20) sampai 8(). dari data terscbut diperoleh range sebesar 60, dengan mcan 33,2614, mcdian 31,000), modus 28,00, dan Standar Deviasi 8,74:174.

Tabel 2: Distribusi Frekuensi Tingkat Kecemasan Somatil Pesilat Grand final Sirkuit Nasional Pencak Silat 2006

\begin{tabular}{|l|c|c|c|}
\hline Kategori & Interval Kclas & Frekucnsi & Persentasc \\
\hline Rendah & $20-40$ & 119 & $77.77 \%$ \\
\hline Sedang & $>40-60$ & 32 & $20.92 \%$ \\
\hline Tinggi & $>60-80$ & 2 & $1.31 \%$ \\
\hline \multicolumn{2}{|c|}{ Jumlah } & 1.53 & $10(0 \%$ \\
\hline
\end{tabular}

3. Tingkat Kecemasan Secara Keseluruhan Pesilat Grand linal Sirkuit Nasional Pencak Silat 2006

Tingkat kecemasan kesclurulıan yang dimaksud addatah kecemasan yang dialami olch pesilat yang terdiri dari kecemasan kognitif maupun kecemasan somatif. 
Tabel 3. Distribusi Frekucnsi Tingkal Kecemasan Sccara Kescluruhan Pesilat Grand linal Sirkuit Nasional Pencak Silat 2006

\begin{tabular}{|c|c|c|c|}
\hline Kategori & Interval Kclas & Frekuensi & Persentase \\
\hline Rendah & $32-64$ & 112 & $73.20 \%$ \\
\hline Sedang & $>64-96$ & 4) & $26.14 \%$ \\
\hline Tinggi & $>96-128$ & 1 & $0.66 \%$ \\
\hline \multicolumn{2}{|c|}{ Jumlah } & 153 & 10()$\%$ \\
\hline
\end{tabular}

\section{Pembahasan}

Berdasarkan hasil penelitian tersebut di atas bahwa tingkat kecemasan kognitif pesilat grand final sirkuit nasional pencak silat 2006 tergolong rendah, terbukti dengan scbagian besar atau 5.5 .55 \% (8.5 orang) atlet terdapat pada kelompok rendah, $43.14 \%$ (66 orang) atlet terdapat pada kelompok sedang dan $1.31 \%$ (2 orang) atlet terdapat pada kelompok tinggi .

Tingkat kecemasan somatif pada pesilat grand linal sirkuit nasional pencak silat 2006 tergolong rendah hal ini sesuai dengan hasil data yang telah diolah menunjukkan bahwa scbesar $77.77 \%$ (11.9 orang) atlet terdapat pada kelompok rendah, 20.92\% (32 orang) atct terdapat pada kclompok scelang dan $1.31 \%$ (2 orang) atlet terdapat pada kelompok tinggi.

Melihat hasil data penelitian di atas dapat dikemukakan bahwa secara keseluruhan tingkat kecemasan pesilat grand final sirkuit nasional pencak silat 2006 tergolong rendah, terbukti secara rinci data menunjukkan sebesar 73.20) \% (112 orang) atlet pada kelompok rendah, 26.14\% (4.) orang) atlet pada kelompok sedang dan $0.66 \%$ (1 orang) atlet pada kelompok tinggi. 
Tingkat kecemasan pesilat tergolong rendah karena pengaruh kualitas pesilat yang sudah terkondisikan dengan dua putaran (sirkuit) tahap sebelumnya di masing-masing wilayah, schingga atlet mempunyai kematangan mental, fisik teknik, maupun taktik. Atlet akan sclalu mclakukan pertandingan, setiap hasil dari pertandingan akan memberikan pengalaman pada individu dan akan memberikan kebiasaan untuk beradaptasi terhadap hasil pertandingan, pada akhirnya bagi atlet yang sudah mengenyam "asam garamnya" hasil pertandingan umumnya menganggap bahwa kemenangan dan kekalahan dalam pertandingan olahraga itu merupakan kejadian yang biasa dan logis (Sukadiyanto, 2005: 7). Untuk itu sclama latihan diperlukan berbagai faktor, khususnya persyaratan pribadi scbagai olahıagawan. Persyaratan pribadi terscbut antara lain scorang olahragawan harus memiliki komitmen, disiplin, tanggung jawab, kemampuan mengendalikan cmosi, rasa percaya diri, dan ketcgasan dalam mengambil keputusan. Sclain itu atlet sudah sering ketemu dalam pertandingan yang menjadikan faktor rendahnya tingkat kecemasan sebelum bertanding. Bebcrapa hal yang juga mempengaruhi tingkat kecemasan pesilat grand linal sirkuit nasional pencak silat 2006 antara lain:

1. Lama Latihan

Prestasi dalam olahraga merupakan suatu proses yang panjang dan tidak dapat diraih secara tiba-tiba atau instant tanpa mclalui proses latihan. Dictrich Harre (1971) menyatakan bahwa latihan adalah suatu proses penyempurnaan olahraga yang diatur dengan prinsip-prinsip yang bersifat ilmiah, khususnya prinsip-prinsip

MEDIKORA Vol.III, No 1, April 20()7: 13()-148 
pedagogis. Mclalui latihan akan berpengaruh terhadap terjadinya adaptasi secara anatomis, psikologis maupun lisiologis atlet dengan karakter suatu cabang olahraga tertentu. Demikian juga pada (abang pencak silat diperlukan adaptasi tersebut agar tercapai kondisi yang prima. Latihan yang teratur, terarah, terprogram dan terencana dengan baik dapat mendukung pencapaian prestasi yang optimal. Latihan yang baik harus direncanakan dengan memperhatikan berbagai hal yang terkait dengan perkembangan atlet scbagai manusia, jenis cabang olahraga, dan tcknologi yang digunakan.

Berdasarkan lama latihan secara kontinyu, bahwa pesilat grand final sirkuit nasional pencak silat 2006 adalah atlet yang terlatih. Atlet yang terlatih mempunyai kecenderungan untuk dapat menguasai permasalahan psikologis dalam bertanding dibandingkan dengan atlet yang belum tidak terlatih. Hal ini sangat mungkin terjadi karena pengalaman latihan yang banyak, maka akan tcrjadi adaptasi anatomis, fisiologis maupun psikologis. Secara otomatis mental atlet akan menyesuaikan dengan kebiasaan bertanding yang merupakan bagian dari sesi latihan. Iebih jelas seperti terlihat pada tabel berikut ini:

Tabel 4. Lama dan Frekuensi Latihan

\begin{tabular}{|c|c|c|}
\hline Lama latihan & Frckucnsi & Persentasc \\
\hline $1-3$ tahun & 51 orang & $33 \%$ \\
\hline $1-6$ tahun & 55 orang & $36 \%$ \\
\hline $7-9$ tahun & 29 orang & $19 \%$ \\
\hline$>9$ tahun & 18 orang & $12 \%$ \\
\hline
\end{tabular}

\footnotetext{
Tingkat Kecemasan Pesilat Grand Fünal Sirkuit Nasional (Tonang, Siswantoyo)
} 
Untuk lebih memahami pengaruh latihan, maka kita dapat melihat konsep adaptasi latihan yang diajukan olch Carlile (19.5.5) yang diadopsi dari Hans Sclyc's Gencral Adaptation Syndromc-GAS (1950).

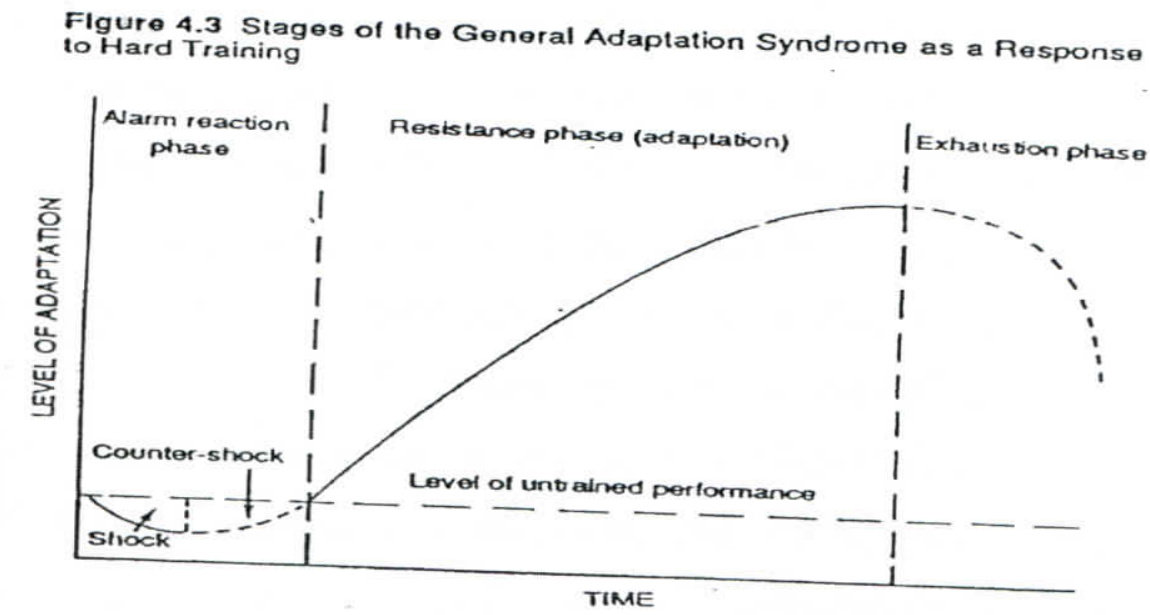

Gambar 1. Teori Tahapan Umum Adaptasi scbagai Respon dari Latihan yang Keras Menurut Carlile (195.5).

Dari gambar di atas kita bisa melihat bahwa secara umum teori adaptasi latihan dibagi menjadi 3 tahapan yaitu:

a. Tahap Reaksi Kegelisahan (Alarm Rcaction Stagc)

Tahap reaksi kegclisahan dibedakan menjadi dua tahapan yaitu Shock dan Countcr Shock Phasc. Shock phasc menggambarkan respon khusus yang dialani atlet terhadap) kcjadian tiba-tiba dan mengcjutkan dari beban kerja yang tidak 
biasa. Hal yang paling bisa diperhatikan dari reaksi yang terjadi saat atlet memulai latihan setelah berhenti. Pada minggu pertama dan kedua latihan awal, latihan itu terasa sulit, mclclahkan, tidak cfisien, kincrja rendah dan penampilan menurun. Counlcr Shock yaitu tahapan dimana gejala yang dialami pada tahap scbelumnya mulai bisa disesuaikan olch tubuh. Melalui latihan secara rutin tubuh telah dapat menyesuaikan terhadap beban berlcbih.

b. Tahap kctahanan (Resislancc Phasc/Adaptation)

Setelah tahap reaksi kegclisahan atlet memasuki tahap ketahanan. Adanya peningkatan ketahanan terhadap latihan ketegangan dan penurunan kctahanan terhadap hal lain. Penampilan meningkat selama tahapan ini. Lamanya tahap kcdua ini tergantung pada latihan dengan beban berlebih yang dijalankan.

c. Tahapan Kclelahan (Exhaustion Phasc)

Tahapan kelelahan ini mengyambarkan reaksi non spesilik yang dihasilkan dari latihan yang (diperpanjang terhadap stress dimana adaptasi tclah dikembangkan tctapi tidak dapat dipertahankan. Pada tahapan ini semua ketahanan rendah dengan stress berlebih selanjutnya menyebabkan elck kronis pada atlet. Pada tingkat kelclahan, kemampuan penampilan memburuk secara cepat dan diringi dengan permasalahan psikologi atlet. 
2. Pengalaman Bertanding

Pengalaman bertanding mempengaruhi kematangan mental pesilat, schingga menjadi salah satu laktor yang mempengaruli tingei rendahnya tingkat kecemasan. Pengalaman bertandling yang dilakukan pesilat grand linal sirkuit nasional pencak silat 2006 mempunyai variasi yang berbeda-beda. Adapun pengalaman bertanding dapat dijclaskan scbagai bcrikut:

a. Pengalaman Bertanding di Tingkat Propinsi

Di beberapa dacrah di Indoncsia yang terbagi dalam wilayah sirkuit nasional pencak silat 2006 masing-masing memiliki kualitas kompetisi lokal yang berbeda. Dacrah-dacrah di pulau Jawa lebih cenderung mendominasi hampir disctiap kcjuaraan nasional, meskipun dalam bebcrapa waktu tcrakhir untuk beberapa propinsi dari luar pulau Jawa seperti Sumatera Sclatan, Sulawesi Selatan dan Sulawaesi Utara mulai menunjukkan kemampuan yang berimbang dengan propinsi di pulau Jawa. Dengan kualitas kompctisi yang tinggi, maka secara otomatis pesilat akan mempunyai pengalaman bertanding yang banyak. Pengalaman bertanding yang banyak mempengaruhi kemalangan mental pesilat, karena hasil menang atau kalah ticlak lagi clirasakan scbagai beban berat yang dapat mengganggu penampilan atlet di arena. Allet hanya akan berusaha bertanding dengan kemampuan terbaiknya anggapan terhadap hasil menang atau kalah sudah menjadi hal yang wajar dalam olahraga kompetisi. Berdasarkan 
pengalaman bertanding di tingkat propinsi dapat digambarkan dalam bentuk table berikut ini:

Tabel 5. Pengalaman Bertanding Atlet Tingkat Propinsi

\begin{tabular}{|c|c|c|}
\hline Pengalaman Bertanding & Frekuensi & Persenlase \\
\hline $1-3$ kali & 63 orang & $41 \%$ \\
\hline $1-6$ kali & 47 orang & $31 \%$ \\
\hline $7-9$ kali & 17 orang & $11 \%$ \\
\hline$>9$ kali & 26 orang & $17 \%$ \\
\hline
\end{tabular}

Hal ini menggambarkan bahwa pesilat grand linal sirkuit nasional pencak silat 2006 adalah atlet dengan pengalaman bertanding ditingkat propinsi yang cukup tinggi.

b. Pengalaman Bertanding di Tingkat Wilayah

Pembagian wilayah dalam sirkuit nasional pencak silat 2006 terdiri dari 7 wilayah dimana setiap wilayah rata-rata terdiri dari 5 propinsi. Pembagian wilayah disatu sisi ada yang menguntungkan sedangkan disisi lai diangyap) merugikan bagi beberapa dacrah tertentu. Hal yang dianggap) menguntungkan adalah untuk daerah dinilai "kuat" (mempunyai potensi pesilat yang bagus) menjadi satu wilayah dengan beberapa dacrah yang dinilai "lemah" (mempunyai potensi pesilat yang kurang bagus dibandingkan daerah lain), schingga dipastikan kompetisi yang berjalan kurang berimbang. Scbagai akibatnya adla beberapa dacrah yang mendominasi perwakilan atlet dari wilayah tertentu. 
Di sisi lain dalam satu wilayah terdiri dari dacrah-dlacrah yang "kuat" schingga kompetisi yang terjadi sangat ketat, kondisi demikian di anggap hal yang merugikan dari sisi dacrah yang bersangkutan.

T'abel 6. Pengalaman Bertanding Atlet Tingkat Wilayalı

\begin{tabular}{|c|c|c|}
\hline Pengalaman Bertanding & Frekuensi & Persentase \\
\hline $1-2$ kali & 60 orang & $39 \%$ \\
\hline $3-4$ kali & 41 orang & $27 \%$ \\
\hline $5-6$ kali & 23 orang & $15 \%$ \\
\hline$>6$ kali & 29 orang & $19 \%$ \\
\hline
\end{tabular}

Hal ini menggambarkan bahwa pesilat grand linal sirkuit nasional pencak silat 2006 adalah atlet dengan pengalaman bertanding ditingkat wilayah yang cukup tinggi.

c. Pengalaman Bertanding di Tingkat Nasional

Pencak silat sebagai olahraga telah berkembang baik di tingkat nasional maupun internasional. Berbagai event sudah tersclenggara seperti discbutkan olch PI3 IPSI diantaranya Kcjurnas putri golongan ramaja dan dewasa, sirkuit nasional, Pckan olahraga pclajar wilayah, Pckan olahraga pclajar nasional, kejuaraan dunia. Sclain itu masih banyak even yang disclenggarakan scperti: Pekan (Olahraga Dacrah (P()RDA), Pekan Olahraga Nasional (PON), dan cvent-cvent lain yang scring diadakan olch dacrah-daerah. Semua even yang telah terselengara

MEDIKORA Vol.III, No 1, April 2(0)7: 13()-1 1.8 
tersebut tentunya memberikan pengalaman bertanding yang cukup bagi pesilat.

Tabel 7. Pengalaman Bertanding Atlet Tingkat Nasional

\begin{tabular}{|c|c|c|}
\hline Pengalaman Bertanding & Frekuensi & Persentasc \\
\hline $1-3 \mathrm{kali}$ & 77 orang & $50 \%$ \\
\hline $4-6 \mathrm{kali}$ & 40 orang & $26 \%$ \\
\hline$>6 \mathrm{kali}$ & 21 orang & $14 \%$ \\
\hline Belum pernah & 15 orang & $10 \%$ \\
\hline
\end{tabular}

Hal ini menggambarkan bahwa pesilat grand linal sirkuit nasional pencak silat 20)(6 adalah atlet dengan pengalaman bertanding ditingkat nasional yang scdang.

Olahragawan akan sclalu mclakukan perlandingan, sctiap) hasil dari pertandingan akan memberikan pengalaman pada indlividu dan akan memberikan kebiasaan untuk beradaptasi tcrhadap hasil pertandingan, pada akhirnya bagi olahragawan yang sudah mengenyam "asam garamnya" hasil pertandingan umumnya menganggap bahwa kemenangan dan kekalahan dalam pertandingan olahraga itu mcrupakan kejadian yang biasa dan logis (Sukadiyanto, 20()5: 7). Untuk itu sclama latilıan diperlukan berbagai laktor, khususnya persyaratan pribadi scbagai olahragawan. Persyaratan pribadi tersebut antara lain scorang olahragawan harus memiliki komitmen, disiplin, tangyung jawab, 
kemampuan mengendalikan emosi, rasa percaya diri, dan ketegasan dalam mengambil keputusan.

d. Pengalaman Bertanding di Tingkat Intcrnasional

Pengalaman bertanding mempengaruhi tingkat kecemasan scbelum bertanding. Dalam hal ini Lutfan Budi Santoso mengungkapkan bahwa keccmasan scbelum bertanding akan dialami oleh siapapun yang akan bertanding, termasuk atlet yang sudah sering bertanding di tingkat internasional sekalipun, hanya yang membedakan adalah tinggi rendahnya kecemasan yang dialami. Ditambahkan lagi olch Lutfan B.S bahwa atlet yang mempunyai pengalaman bertandling yang banyak alau "jam terbang tinggi” akan dapat mengelola kecemasan yang scring dirasakan pada saat akan berlanding.

Tabel 8. Pengalaman Bertanding Tingkat Intcrnasional

\begin{tabular}{|c|r|c|}
\hline $\begin{array}{c}\text { Pengalaman } \\
\text { Bertanding }\end{array}$ & Frekuensi & Pcrscntase \\
\hline 1 kali & 14 orang & $9 \%$ \\
\hline 2 kali & 3 orang & $2 \%$ \\
\hline$>2$ kali & 5 orang & $3 \%$ \\
\hline Belum pernah & 132 orang & $86 \%$ \\
\hline
\end{tabular}

Hal ini menggambarkan bahwa pesilat grand linal sirkuit nasional pencak silat 2006 adalah atlet dengan pengalaman bertanding ditingkat internasional yang rendah. 
Dari data hasil penclitian terscbut menjadi informasi penting bagi pelatih pencak silat dalam mengambil langkahlangkah nyata untuk mengatasi permasalahan mental atlet pencak silat. Pelatih harus tetap dan lebih aktif dalam membcrikan program latihan yang mengarah ke laktor psikologis dalam sctiap) scsi latihan agar kondisi yang sudah ada tidak menurun melainkan akan tcrus meningkat.

\section{KESIMPULAN}

Sesuai dengan hasil penelitian dan pembahasan yang telah diuraikan di atas, dapat simpulkan bahwa pesilat Grand linal Sirkuit Nasional Pencak Silat 2006 mengalami tingkat kecemasan scbelum bertanding yang rendlah.

\section{Daftar Pustaka}

Bompa, T.O. (1994). Theory and Methodology of Training: Dubuque Iowa:Kendal hunt Publishing Company.

Cox. Richard H, Martens Matthew P, and Russell William D). (20)(3). Mcasuring Anxicty in Athletics: The Rerised Compertitio Statc Anxicty Inventory-2. Australia: The university of Western Australian Crawley.

Gunarsa, S.D., dkk. (1989). Psikologi Olahraga. Jakarta: P.T. BPK (junung Mulia.

http://www.bulutangkis.com/mod.php? $\bmod =$ userpagc\&menu=4() $3 \&$ page $i \mathrm{id}=$ $\underline{7 \& \text { PHPSESSID }=7 \mathrm{bc} 6519 \mathrm{al} 50.55 \mathrm{cl} 918[96 \mathrm{cc} 6}$.

Lutfan Budi Santoso. (2006). Interview. 18 November 2006. Jakarta 
Martens, Ranncr. (1977). Sports Compctition Anvicty Tcst. Illinois: Human Kinctics Publisher.

Notosoejitno. (1997) Khasanah Pencak Silat. Jakarta: CV. Inlomedika.

O'ong Maryono. (1998). Pcncak Silat; Waktu Mcrentang: Yogyakarta: Pustaka Pclajar.

Pate, Rotella dan Mc Clenaghan (1993). Dasar-Dasar Ilmiah kepclati han (Terjemahan Kasiyo Dwijowinoto) Scmarang: IKIP Scmarang Press.

PB.IPSI. (2003). Pcraturan Pcrtandingan Pcncak Silat Ikatan Pcncak Silat Indonesia; Hasil Kcputusan Munas IPSI XI 20033. Jakanta.

Soedjono dan Ndong Kamtomo. (1986). Psikologi Olahraga. Yogyakarta: FPOK IKIP Yogyakarta.

Sudibyo Setyabrata. (2002). Psikologi Olahraga. Jakarta: P.T Ancm Kosong.

Suharsimi Arikunto. (1998). Proscdur Pcnclitian Suatu Pcndckatan Praktck. Jakarta: PT. Ricnika Cipta.

Sumadi Suryabrata. (1982). Psikologi Kepribadian. Jakarta: CV. Rajawali (1989). Psikologi Pendidikan. Jakarta: CV. Rajawali.

Sukadiyanto. (2005). Pcrmasalahan Mcntal Atlct. Mạjalah Olahıraga. Yogyakarta. FIK UNNY.

Sutrisno Hadi (1990). Mctodologi Research. Yogyakarta: Andi Ollsct.

Weinberg R.S \& Gould.D. (20)3). Foundations of Sports \& Excreisc Psychology. Inited States. Human Kinctics.

MEDIKORA Vol.III, No 1, April 2007: 130-148 